\title{
PUSAT PERAWATAN DEPRESI REMAJA DI BANJARBARU YOUTH TREATMENT CENTER BANJARBARU
}

\author{
Ditha Tiara Sukma \\ Program Studi Teknik Arsitektur Fakultas Teknik Universitas Lambung Mangkurat \\ 1610812220006@ulm.ac.id
}

\section{Bani Noor Muchamad}

Program Studi Teknik Arsitektur Fakultas Teknik Universitas Lambung Mangkurat bani.nm@ulm.ac.id

\begin{abstract}
ABSTRAK
Depresi merupakan suatu kondisi medis yang berdampak negatif terhadap pikiran, tindakan, perasaan, dan kesehatan mental seseorang. Penderita depresi cenderung merasa terjebak dalam kondisi yang tidak ada harapan, tidak ada pertolongan, penuh penolakan, perasaan tidak berharga, hingga mendorong penderitanya untuk melakukan bunuh diri. Menurut data Kementerian Kesehatan, penderita gangguan mental emosional pada penduduk berusia diatas 15 tahun di Kalimantan Selatan mengalami peningkatan. Selain itu, Kalimantan Selatan hanya memiliki fasilitas bagi pengidap gangguan jiwa berat, belum ada fasilitas khusus untuk menangani penderita gangguan mental ringan khususnya depresi. Terdapat banyak remaja yang mengalami depresi namun, sangat sedikit yang meminta bantuan tenaga profesional karena banyaknya stigma negatif di kalangan masyarakat serta kurangnya pemahaman, menghalangi para penderita depresi mendapatkan pertolongan yang tepat. Rancangan bangunan Youth Treatment Center menggunakan metode psikologi gestalt dengan konsep space perception. Rancangan ini memiliki tujuan sebagai fasilitas perawatan penderita depresi pada remaja yang dapat merubah stigma negatif dan meningkatkan kesadaran masyarakat tentang pentingnya isu kesehatan mental.
\end{abstract}

Kata kunci: Kesehatan Mental, Depresi, Remaja, Stigma.

\begin{abstract}
Depression is a medical condition that negatively impacts a person's thoughts, actions, feelings, and mental health. Depressed individuals tend to feel trapped in a hopeless condition, no help, full of rejection, feeling worthless, which encourages the sufferer to commit suicide. According to data from The Ministry of Health shows that the prevalence of mental emotional disorders in people aged over 15 years in South Kalimantan has increased. In addition, South Kalimantan only has facilities for people with severe mental illness, there are no special facilities to treat people with mental disorders especially depression. There are many young people who have depression however, not much of them asking for professional help because of stigma among society and a lack of understanding, preventing people with depression from getting proper help. Design of Youth Treatment Center applied method gestalt psychology and space perception concept. This design is to provide a
\end{abstract}


treatment for depression adolescents that can change stigma and increase public awareness of mental health.

Keywords: Mental Health, Depression, Youth, Stigma

\section{PENDAHULUAN}

Menurut survei yang dilakukan oleh World Health Organization (WHO), sekitar $20 \%$ remaja di dunia mengalami gangguan kesehatan mental berupa depresi. Menurut WHO, pada tahun 2020 depresi berada pada urutan ke-2 penyakit di dunia setelah penyakit jantung dan menjadi sebuah "krisis global". Jika dilihat situasi saat ini, laporan menunjukkan adanya peningkatan kasus dan gangguan kesehatan mental yang menyebabkan tekanan psikologis ditengah pandemi virus corona (COVID-19). Selain itu, lebih dari 800.000 orang setiap tahunnya meninggal karena bunuh diri yang diakibatkan oleh depresi. Bunuh diri akibat depresi menjadi penyebab terbesar kedua kematian di dunia yang terjadi pada usia 15 tahun hingga usia 19 tahun. Data Riskesdas Tahun 2018 yang dilaporkan Kementerian Kesehatan Republik Indonesia menunjukkan bahwa, prevalensi gangguan mental emosional pada penduduk berusia diatas 15 tahun naik menjadi 9,8 setelah sebelumnya tahun 2013 berada pada angka 6 .

Terdapat lebih dari 15 juta penduduk Indonesia usia di atas 15 tahun terkena gangguan mental emosional berupa depresi, dan sebagian besar adalah wanita. Namun, hanya $8 \%$ yang meminta bantuan tenaga profesional seperti psikolog maupun psikiater. Banyaknya stigma negatif di kalangan masyarakat serta kurangnya pemahaman, menghalangi para penderita depresi mendapatkan dukungan yang tepat untuk mencari bantuan. Stigma adalah sebuah fenomena yang terjadi ketika seseorang diberikan labeling, stereotip, separation dan mengalami diskriminasi (Schied dan Brown, 2010). Menurut UUD 1945 Nomor 18 Tahun 2014 Tentang Kesehatan Jiwa, menjamin setiap orang dapat hidup sejahtera lahir dan batin serta memperoleh pelayanan kesehatan dengan penyelenggaraan pembangunan kesehatan yang memiliki tujuan terwujudnya derajat kesehatan yang setinggi-tingginya. Untuk mencapai tujuan tersebut, perlu dilakukan berbagai upaya kesehatan termasuk upaya kesehatan jiwa dengan pendekatan promotif, preventif, kuratif, dan rehabilitatif.

Berdasarkan prevalensi depresi penduduk usia 15 tahun keatas menurut Laporan Nasional Riskesdas Tahun 2013, Kalimantan Selatan memiliki angka prevalensi sebesar 5,1 dari rata-rata Indonesia sebesar 6,1. Angka tersebut mengalami kenaikan pada tahun 2018 menjadi 7,5 dari angka rata-rata Indonesia sebesar 9,8. Selain itu, Kalimantan Selatan hanya memiliki fasilitas bagi pengidap gangguan jiwa berat (psikosis) yakni Rumah Sakit Jiwa Sambang Lihum, Panti Sosial Bina Laras dan Budi Luhur (PSBL). Belum ada fasilitas khusus untuk menangani penderita gangguan kesehatan mental ringan (neurosis). Fasilitas kesehatan mental masih berpusat pada rumah sakit jiwa yang merupakan tempat rehabilitasi untuk gangguan jiwa berat, sedangkan cara pengobatan depresi dan gangguan jiwa sangat berbeda dan tidak bisa disamakan. Kurangnya perhatian serius terhadap isu kesehatan mental khususnya depresi, menyebabkan sering terjadinya pemahaman yang salah akan pengobatan secara tepat. Menurut data Kementrian Kesehatan, masyarakat perkotaan lebih rentan mengalami depresi karena tingkat mobilitas dan kepadatan penduduknya yang tinggi. Sudah banyak terdapat biro-biro konsultasi psikologi yang tersebar di lebih dari dua puluh titik di Banjarmasin dan Banjarbaru namun, fasilitas yang disediakan belum bisa memenuhi kebutuhan penderita depresi secara maksimal sesuai dengan spesifikasi permasalahannya.

Berdasarkan hasil wawancara dengan Ibu Shanti Komalasari, M. Psi., selaku pemilik Konsultan Psikologi dan 
Pusat Pengembangan Karakter di Banjarbaru, diperlukan pusat perawatan depresi pada remaja sebagai fasilitas untuk menjawab permasalahan masyarakat urban sesuai dengan tingkat kebutuhan dan harus terpusat. Remaja dan dewasa muda memiliki kemampuan otak bagian depan yang belum berfungsi secara maksimal akibat peralihan usia dari anak-anak menuju dewasa. Selain itu, remaja memiliki faktor hormonal fluktuatif dan kondisi emosional yang tidak stabil serta neuropsikologis yang belum berkembang secara sempurna. Sehingga, mudah untuk mengalami permasalahan depresi, dari tingkat depresi ringan hingga berat.

Kesehatan mental bagi remaja sangat penting karena berpengaruh pada pertumbuhan dan perkembangan psikologis dalam menuntaskan tugas-tugasnya. Jika remaja sehat secara mental, maka mereka akan dapat banyak belajar memahami jati diri menjadi pribadi yang lebih positif dan matang. Hal ini akan berpengaruh terhadap cara berpikir positif dan perilaku yang muncul pun adaptif. Sebaliknya, jika kondisi mental remaja tidak sehat seperti mengalami depresi, remaja akan lebih banyak berpikir negatif, mengalami kesesatan dalam berpikir, hingga keliru dalam mempersepsikan sesuatu sampai pada muncul perilaku-perilaku yang maladaptif bahkan bunuh diri. Rendahnya kesadaran dan belum banyak masyarakat menyadari pentingnya kesehatan mental, seperti mengabaikan pemeriksaan psikologis karena masih melekatnya stigma negatif terkait permasalahan psikologis yang disamaratakan dengan gangguan jiwa berat (psikotik). Meminta bantuan ke psikolog dianggap mempunyai permasalahan klinis yang serius. Padahal dengan memeriksakan diri merupakan dukungan psikologis awal (psychological first aid) yang sangat membantu gejala-gejala awal untuk segera ditangani.

\section{PERMASALAHAN}

Banyaknya stigma negatif yang melekat pada masyarakat mengenai penderita gangguan kesehatan mental yang sering dihakimi maupun fasilitas kesehatan mental yang dianggap memiliki citra menakutkan. Persepsi negatif tersebut mempengaruhi banyak hal, terutama menjadi penghalang bagi penderita depresi untuk sembuh dan terjebak dalam lingkungan yang tidak mendukung akibat kurangnya pemahaman mengenai kesehatan mental. Semua hal yang bersifat negatif tersebut diatasi melalui media arsitektur yaitu dengan rancangan bangunan Youth Treatment Center yang memiliki citra positif sehingga dapat berperan dalam menciptakan lingkungan psikologis yang lebih baik. Sehingga permasalahan arsitektur yang diangkat yaitu bagaimana rancangan fasilitas kesehatan mental sebagai wadah perawatan penderita depresi pada remaja sekaligus menjadi bangunan yang memiliki citra positif serta dapat merubah stigma negatif dan meningkatkan kesadaran masyarakat?

\section{TINJAUAN PUSTAKA}

\section{A. Tinjauan Pusat Perawatan Depresi Remaja}

1. Pusat Perawatan

Menurut Poerwadarminta (2003) pusat adalah pokok atau pangkal berbagai urusan, hal dan sebagainya. Tempat yang memiliki aktivitas tinggi serta menarik dari daerah sekitarnya. Sedangkan perawatan adalah proses yang berhubungan dengan pencegahan, manajemen penyakit, juga proses stabilisasi mental, fisik serta rohani melalui pelayanan oleh organisasi dan unit profesional. Sehingga pengertian dari pusat perawatan adalah tempat yang memiliki aktivitas tinggi berupa pelayanan stabilisasi mental oleh unit profesional. Youth Treatment Center sebagai Mental Health Care memiliki fungsi sebagai fasilitas pelayanan untuk perawatan gangguan 
kesehatan mental ringan yang dapat memperbaiki, memperkuat, meningkatkan kemampuan fungsi yang dibutuhkan dalam proses penyesuaian diri dengan lingkungan meningkatkan produktivitas dan memelihara kesehatan mental serta menciptakan kesejahteraan psikologis (psychological wellbeing).

\section{Remaja}

Menurut Hurlock (1999) istilah adolescence atau remaja berasal dari kata latin yang berarti tumbuh menjadi dewasa. Secara psikologi masa remaja adalah usia dimana individu berintegrasi dengan masyarakat dewasa, tidak lagi merasa dibawah tingkat orang-orang yang yang lebih tua melainkan berada dalam tingkatan yang sama (Piaget, 1980). Menurut Santrock (2013), Remaja diartikan sebagai masa transisi antara masa anak-anak dan masa dewasa yang mencakup perubahan biologis, kognitif, dan sosial-emosional. Peraturan Menteri Kesehatan RI Nomor 25 Tahun 2014 menyebutkan bahwa, remaja adalah penduduk dalam rentan usia 10 hingga 19 tahun. Sedangkan menurut BKKBN, remaja adalah penduduk dalam rentan usia 12 hingga 24 tahun dan belum menikah.

\section{Depresi}

Menurut Semiun (2006), istilah "kesehatan mental" diambil dari konsep mental hygiene. Kata mental diambil dari Bahasa Yunani yang artinya psikis, jiwa atau kejiwaan. Menurut Dr. Zakiah Daradjat (1985), kesehatan mental adalah keserasian atau kesesuain antara seluruh aspek psikologis yang dimiliki oleh seseorang untuk dikembangkan secara optimal agar individu mampu melakukan kehidupan sesuai dengan nilai-nilai yang berlaku secara individual, kelompok, maupun masyarakat luas sehingga dapat sehat baik secara mental maupun secara sosial. Menurut Nevid (2005), depresi adalah gangguan mood yang mempengaruhi perubahan pada kondisi emosional, motivasi dan fungsi, perilaku motorik serta perubahan kognitif. Ciri-ciri gejala depresi berdasarkan panduan The Diagnostic and Statistical Manual of Mental Disorders Fifth Edition DSM-5 (2013) yaitu, mengalami penurunan suasana hati hampir sepanjang hari, adanya penurunan minat pada aktivitas sehari-hari, penurunan berat badan yang signifikan, permasalahan tidur seperti insomnia dan hipersomnia, penurunan kemampuan berpikir, mengalami kelelahan dan kehilangan energi, merasa tidak berharga atau rasa bersalah yang berlebih, kesulitan berkonsentrasi dan berkurang nya kemampuan berpikir, serta sering memiliki keinginan untuk mengakhiri hidup yang berlangsung selama minimal dua minggu. Depresi terbagi menjadi tiga tingkat yaitu depresi ringan, sedang dan berat.

\section{B. Tinjauan Konsep}

Menurut buku Gestalt Psychology: The Definitive Statement of The Gestalt Theory (1970), psikologi gestalt merupakan sebuah teori yang membahas tentang persepsi manusia terhadap sebuah keseluruhan dan kesatuan bentuk. Gestalt merupakan kata dari Bahasa Jerman yang diartikan sebagai bentuk. Teori ini dikemukakan oleh Max Wertheimer, Kurt Koffka, dan Wolfgang Kohler (1910) yang menitikberatkan pada bagaimana hubungan antara bentuk-bentuk yang dapat ditemukan di lingkungan sekitar akan berpengaruh terhadap persepsi satu kesatuan dan keseluruhan. Gestalt merupakan teori persepsi yang paling banyak berpengaruh dalam bidang seni dan arsitektur dengan mengungkapkan berbagai fenomena visual. Menurut Wood (2006), persepsi adalah sebuah proses yang aktif dari manusia dalam memilah, mengelompokkan, serta memberikan makna pada informasi yang diterimanya. Dalam teori gestalt, hal yang perlu diperhatikan adalah konsep tentang form dan keseluruhan lebih penting daripada bagian-bagiannya. Terdapat enam prinsip dalam teori gestalt yaitu, kedekatan (proximity), similaritas (similarity), ketertutupan (closure), bidang dan simetri 
serta bentuk dan latar (figure and ground). Menurut Bill Canton (1990), citra adalah kesan, perasaan, dan gambaran dari pemahaman seseorang terhadap suatu objek. Unsur-unsur visual ditransfer sebagai wujud yang akan menstimulasi dan merangsang perhatian pengamatan, kemudian dipersepsi menjadi nilai yang mempengaruhi pembentukan image.

\section{PEMBAHASAN}

\section{A. Lokasi}

Perancangan Youth Treatment Center berlokasi di jalan Ahmad Yani, Loktabat Selatan, Kecamatan Banjarbaru Selatan, Kota Banjarbaru, Kalimantan Selatan. Tapak berbentuk persegi panjang dengan luas sebesar $8.250 \mathrm{~m} 2$. Berdasarkan tujuan yang ingin dicapai yaitu merubah stigma dan meningkatkan kesadaran masyarakat, pemilihan lokasi berada di area pusat kota karena memiliki intensitas aktivitas yang tinggi. Tapak berada di zona komersial dan pendidikan yang merupakan lokasi strategis, sehingga dapat sangat mudah untuk dijangkau. Lokasi tersebut sering dilalui oleh anak muda, remaja, pelajar dan mahasiswa. Tapak berdekatan dengan banyak institusi pendidikan seperti Kawasan Universitas Lambung Mangkurat dan berhadapan langsung dengan Fakultas Kedokteran ULM Banjarbaru yang memiliki Program Studi Psikologi.

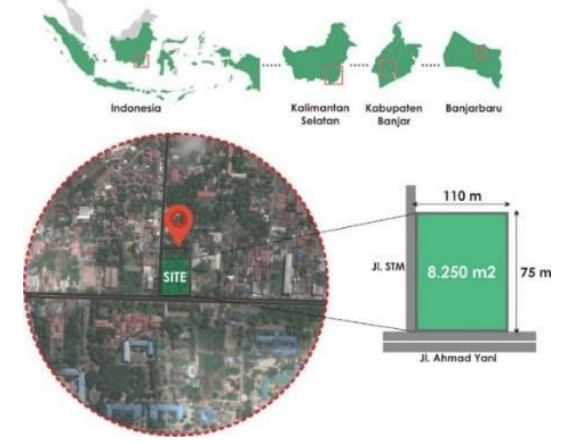

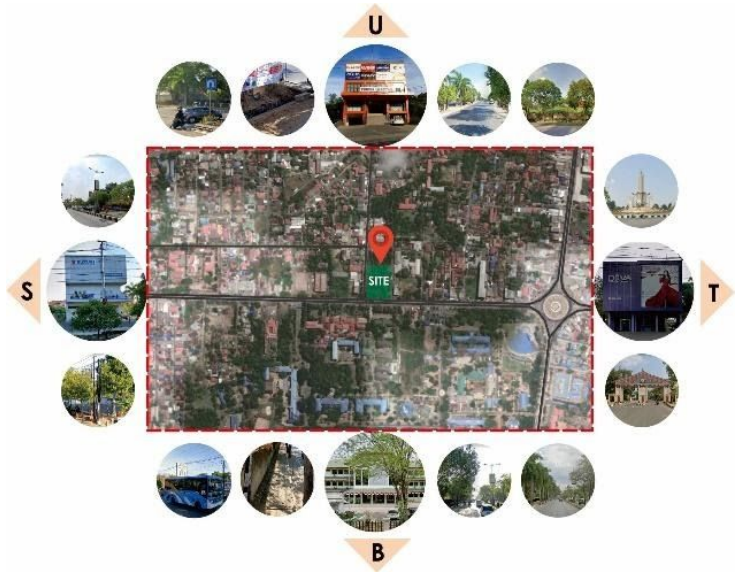

Gambar 1. Eksisting Tapak

Sumber: Analisis Pribadi (2020)

\section{B. Konsep Rancangan}

Konsep space perception diterapkan sebagai jawaban dari permasalahan. Dimana konsep ini berfokus pada aspek psikologis, menciptakan citra bangunan yang positif dan bersifat edukatif dipadukan dengan metode persepsi dari teori gestalt. space perception menekankan pada pembentukan persepsi secara psikologis melalui indera dengan elemen arsitektur seperti bentuk, warna, material dan tekstur untuk menciptakan citra positif pada bangunan. Konsep ini dianggap mampu menyelesaikan masalah stigma secara arsitektural sehingga menciptakan ruang yang dapat membangun persepsi positif. 


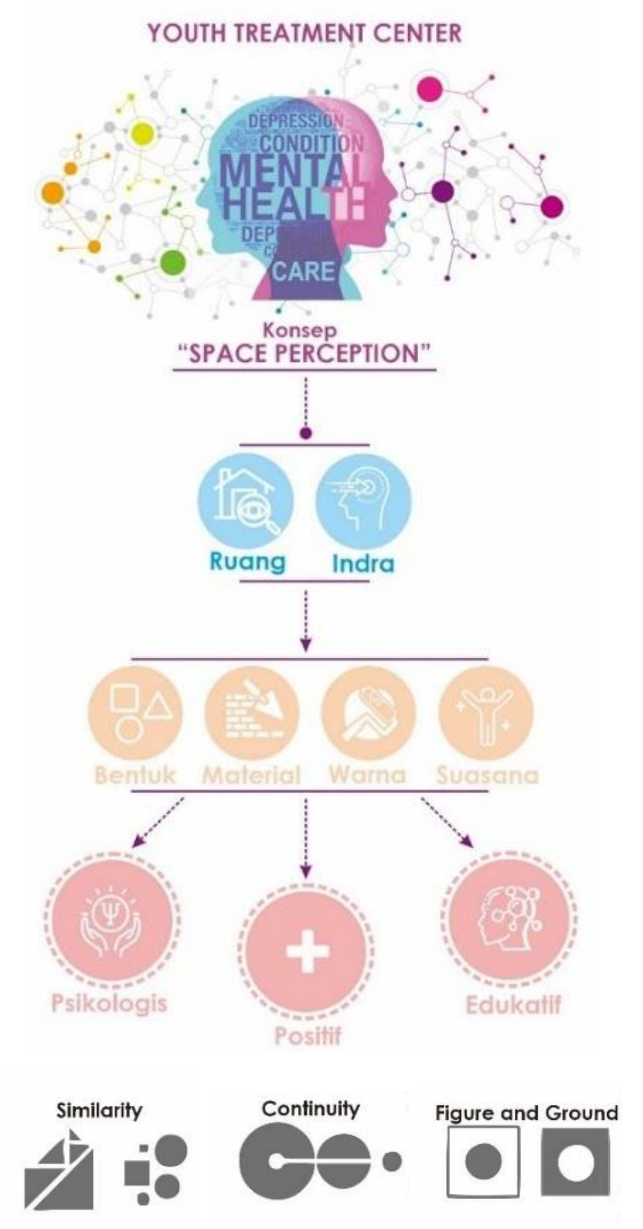

Gambar 2. Konsep

Sumber: Analisis Pribadi (2020)

\section{Tata Masa}

Bentuk bangunan Youth Treatment Center merupakan transformasi dari bentuk neuron, yaitu sistem saraf otak yang berfungsi menghantarkan impuls dan terbentuk akibat adanya sensorik (rangsangan). Bentuk ini dipilih karena depresi sendiri merupakan gangguan medis akibat adanya gangguan pada neurotransmitter dalam otak yang berperan dalam mengontrol kestabilan suasana hati. Desain bangunan yang memiliki bentuk dasar lingkaran dengan mempertimbangkan tiga prinsip teori gestalt yakni continuity (kesinambungan). Sedangkan desain tapak dibuat menyerupai bentuk kepala manusia yang tersusun dari empat lingkaran dan bangunan sebagai pusat pikirannya, karena diambil dari kata mental yang berarti pikiran.

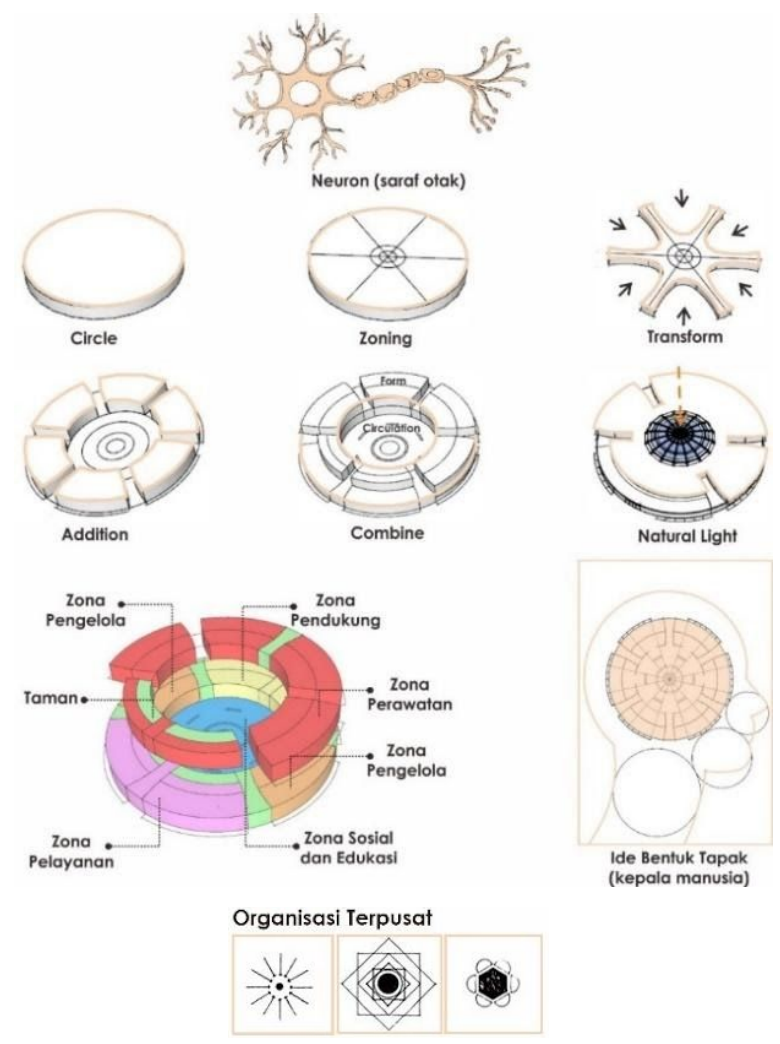

Gambar 3. Konsep Bentuk

Sumber: Analisis Pribadi (2020)

\section{Zoning}

Terdapat enam pembagian zona berdasarkan sifat dan fungsi ruangnya. Zona pelayanan merupakan zona untuk melayani penderita yang ingin melakukan perawatan atau masyarakat yang ingin mencari informasi mengenai kesehatan mental. Zona pengelola adalah area kantor bagi tenaga ahli seperti psikiater, psikolog dan terapis. Zona perawatan digunakan sebagai zona bagi penderita depresi untuk melakukan perawatan seperti konseling dan terapi sehingga memiliki tingkat privasi yang tinggi. Zona sosial sebagai area untuk bersosialisasi antara pengguna bangunan untuk bisa terbuka mengenai kesehatan mentalnya. Zona servis merupakan zona untung ruang-ruang pendukung dan area parkir. Selain itu, terdapat juga zona open 
space dimana sebagai area untuk ruang terbuka hijau dan taman terapeutik.

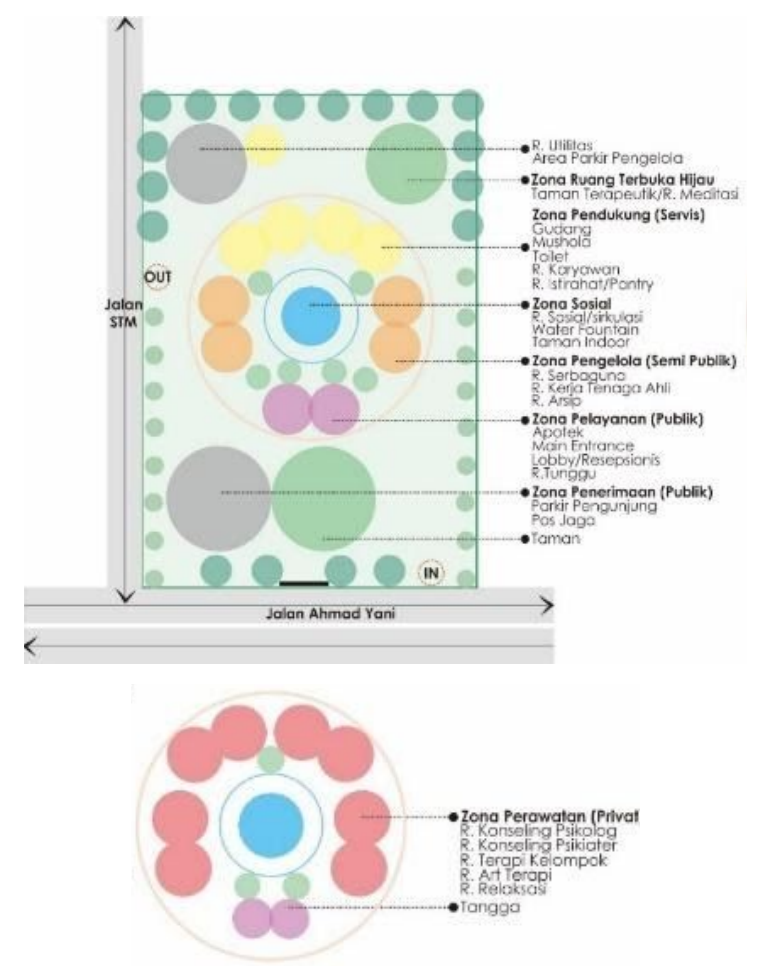

Gambar 4. Konsep Zoning

Sumber: Analisis Pribadi (2020)

\section{Sirkulasi}

Sirkulasi untuk mencapai setiap ruang pada bangunan dibuat melingkar mengikuti bentuk dasar bangunan, sehingga menciptakan sensasi atau pengalaman ruang yang menarik. Sirkulasi dengan bentuk melingkar merupakan salah satu penerapan dari prinsip gestalt yaitu continuity (kesinambungan). Selain itu, ruang sosial dengan water fountain sebagai pusat bangunan dan sirkulasi melingkar memberikan kesan ruang lebih luas, rasa kedekatan, dan keterbukaan sosial serta dapat dimanfaatkan untuk berbagai macam fungsi dan aktivitas seperti area untuk berinteraksi, bersosialisasi, mendapatkan informasi dan edukasi.

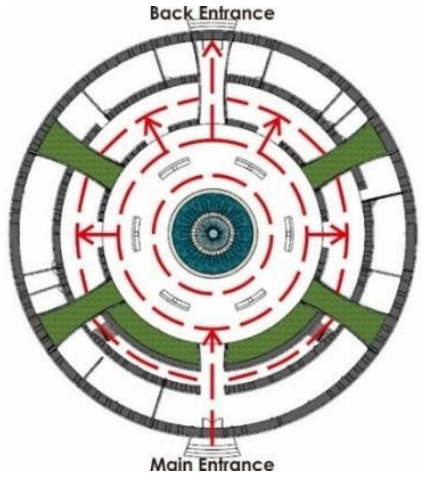

Gambar 5. Konsep Sirkulasi

Sumber: Analisis Pribadi (2020)

\section{Ruang}

Youth Treatment Center sebagai fasilitas untuk penderita depresi yang ingin meminta bantuan tenaga profesional dan melakukan perawatan seperti konseling dan terapi agar bisa sembuh dari depresi. Persepsi positif yang ingin dibentuk sendiri bukan hanya persepsi dari penderita depresi, melainkan juga persepsi masyarakat luas tentang pentingnya kesehatan mental dengan adanya program edukasi dan sosialisasi. Persepsi penderita depresi yang akan dibentuk yaitu akan timbul rasa percaya dan terbuka untuk mengungkapkan segala permasalahan serta emosi negatif yang terpendam tanpa takut untuk untuk dihakimi ataupun direspon dengan buruk. Sehingga akan terjalin hubungan emosional yang nyaman, membuat perasaan penderita depresi menjadi jauh lebih baik. Sedangkan masyarakat akan terbuka pikirannya sehingga kesadarannya terhadap gangguan kesehatan mental meningkat dan persepsi negatif perlahan-lahan dapat berubah. 


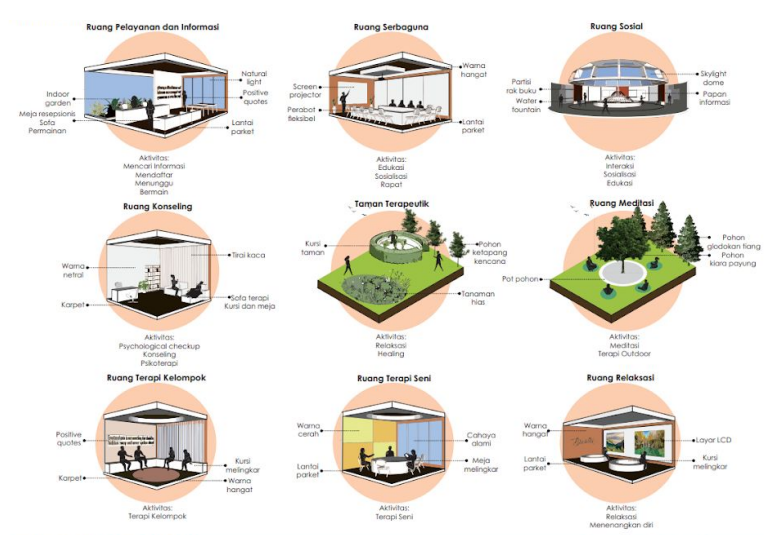

Gambar 6. Konsep Ruang

Sumber: Analisis Pribadi (2020)

5. Tampilan Visual

Tampilan visual bangunan yang memiliki informasi, emosi, impresi dan sesuai dengan konteks dapat mempengaruhi mental set pengamatnya. Diharapkan bangunan Youth Treatment Center dapat merubah semua hal bersifat negatif tersebut menjadi hal yang positif (turn negativity into positivity). Oleh karena itu, eksterior didesain dengan menggunakan letter façade yang berisikan kata-kata positif sebagai wajah untuk menonjolkan tampilan visual bangunan dengan menerapkan prinsip gestalt yaitu similarity (kesamaan). Letter facade merupakan bentuk support emosional dalam upaya untuk meningkatkan kesadaran mengenai kesehatan mental. Diharapkan masyarakat yang melihatnya dapat berpersepsi positif sehingga dapat menimbulkan citra positif pada bangunan.

FASAD A

Take a depp breath and smilie Self care isn't selfish Think Pusitive Mental disorder is nothing to be ashamed of Life is beautiful but stigma and bias shame us all Taday chuoce life and Happiness You are amazingperson Love Your Mind Love Yaurself Keep Gaing Keep Growing Calm yourself the storm will pass Please ton't Give in

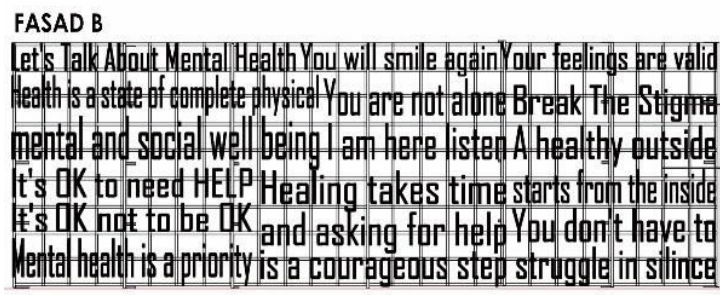

\section{Gambar 7. Konsep Tampilan Visual} Sumber: Analisis Pribadi (2020)

\section{Warna}

Pengaplikasian warna ruangan pada bangunan disesuaikan berdasarkan makna psikologis. Dominasi warna warmtone dipilih untuk memberikan rasa hangat. Warna coklat, kuning dan jingga memiliki berbagai makna positif yang dapat meningkatkan kenyamanan dan membangkitkan semangat dengan kombinasi sentuhan natural tone yang memiliki kesan alami yaitu warna hijau dan biru berupa elemen vegetasi dan air.
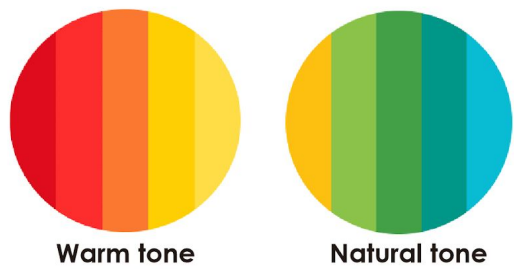

Gambar 8. Konsep Warna

Sumber: Analisis Pribadi (2020)

\section{Suasana}

Suasana yang ingin diciptakan yang dapat memberi kesan tidak menakutkan positif, bebas tekanan, akrab, terbuka, dan membuat penderita depresi merasa lebih baik. Unsur-unsur alam yang merelaksasi dengan sentuhan elemen air, suara kicauan burung jenis lovebird dan berbagai macam tanaman, dapat membuat perasaan menjadi lebih tenang dan damai. Hal ini juga dapat melatih kepekaan indra sehingga dapat menimbulkan efek psikologis yang baik untuk mendukung proses perawatan.

$$
\text { Pengalaman multi sensorial }
$$
disuguhkan pada pengunjung dengan menerapkan elemen-elemen pembentuk ruang. Indra penglihatan mendominasi dalam pengalaman ruang dengan menerapkan warna hangat, bentuk dinamis, cahaya alami dan taman terappeutik yang merelaksasi pandangan. Indra pendengaran dari suara gemericik air, kicauan burung, dan alunan relaxing musik pada interior bangunan dapat memberikan ketenangan dan meningkatkan kenyamanan ruang. Aromatherapy dapat diletakkan di setiap 
ruang untuk membantu meredakan stres dan merangsang indra penciuman. Indra peraba dengan penggunaan material alami seperti kayu dan batu alam yang memiliki tekstur halus berperan besar dalam identifikasi ruang.
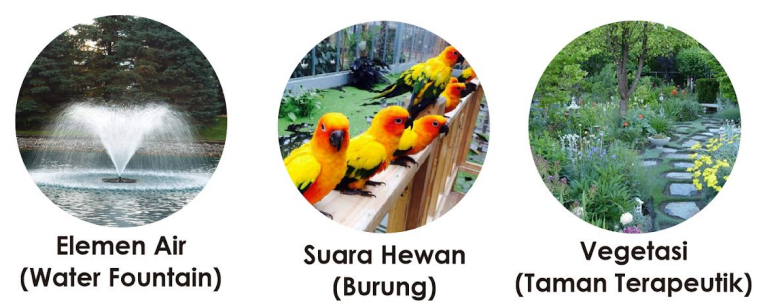

Gambar 9. Konsep Suasana Sumber: Analisis Pribadi (2020)

\section{Vegetasi}

Vegetasi pada rancangan dibedakan menjadi dua yaitu vegetasi untuk area outdoor berupa pepohonan dan Terdapat taman-taman indoor di setiap pembagian zona ruang karena mempunyai efek psikologis yang menenangkan. Jenis-jenis tanaman hias pada interior bangunan yaitu english ivy, rubber tree, lily snake plant, spider plant, golden pothos, dan lavender. Lahan pada tapak yang tidak terbangun, diolah menjadi taman karena dapat memberikan kesan sejuk, segar serta mampu mereduksi rasa stres.

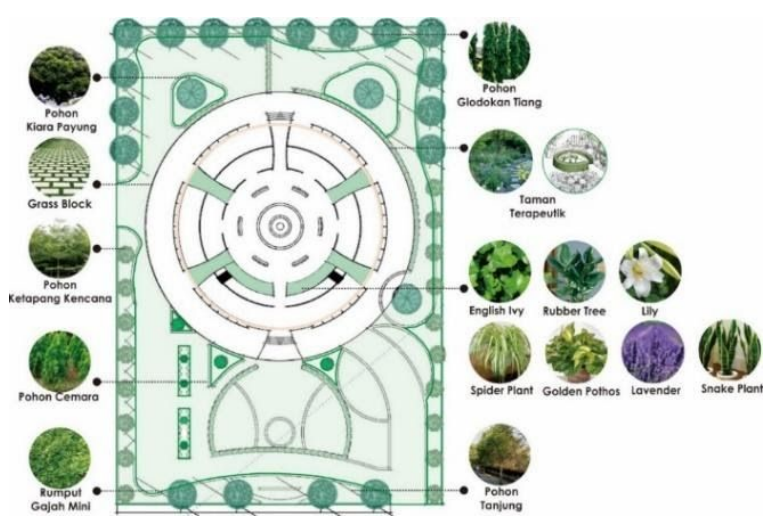

Gambar 10. Konsep Vegetasi

Sumber: Analisis Pribadi (2020)
9. Struktur

Struktur atap menggunakan skylight dome yang tersusun dari material baja ringan yang dikombinasikan dengan atap dak. Kaca atap skylight yang digunakan yaitu laminated tempered yang memiliki daya tahan sangat tinggi dengan fitur anti sinar UV untuk mencegah panas saat siang hari. Badan bangunan menggunakan struktur dinding batu bata dengan finishing eksterior wood plastic composite panel untuk memberikan kesan alami. Sedangkan struktur bawah menggunakan pondasi foot plat.

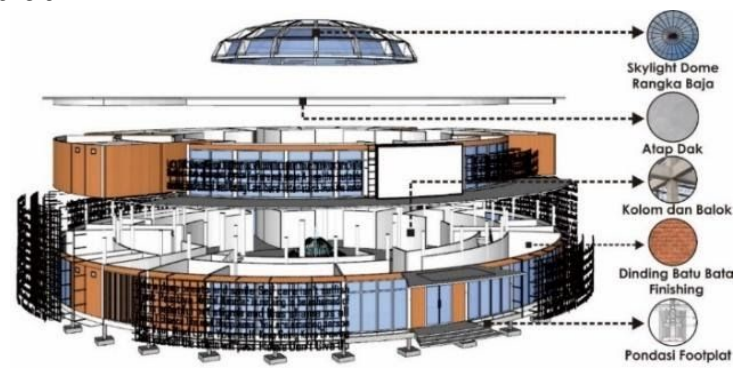

Gambar 11. Konsep Struktur Sumber: Analisis Pribadi (2020)

\section{HASIL}

Hasil rancangan menerapkan tiga prinsip teori gestalt yaitu Similarity yang diterapkan pada tekstur, warna, suasana dan desain eksterior yang dihiasi letter façade disusun mengikuti bentuk bangunan. Continuity diterapkan pada bentuk dan sirkulasi bangunan berupa lingkaran yang memberikan kesan dinamis. Figure and ground diterapkan pada bentuk bangunan sebagai figur dan lanskap sebagai ground sehingga bangunan yang terlihat menonjol dari lingkungan sekitarnya dapat memberikan daya tarik dan perceptual field yang memberikan makna.

\section{Site Plan}




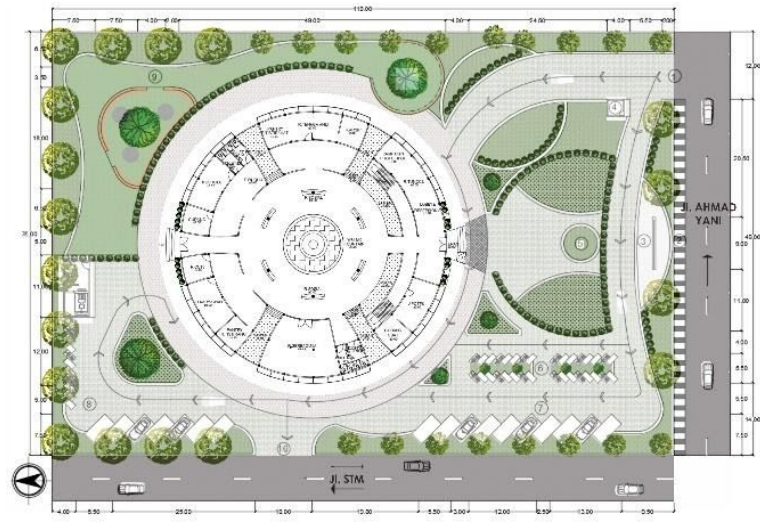

Gambar 12. Perspektif Interior Sumber: Analisis Pribadi (2020) 2. Tampak

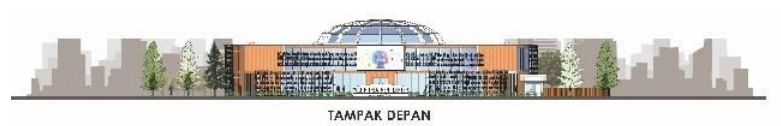
TAMPAK DEPAN
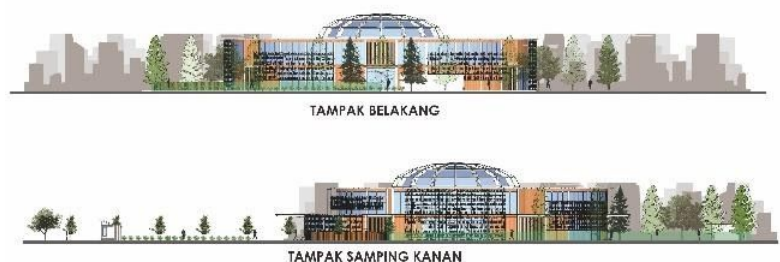

TAMPAK SAMPING KANAN

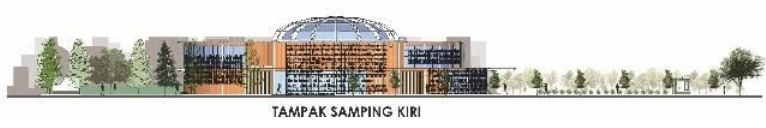

Gambar 13. Perspektif Interior Sumber: Analisis Pribadi (2020)

\section{Perspektif Interior}

\section{Lobby/Resepsionis}

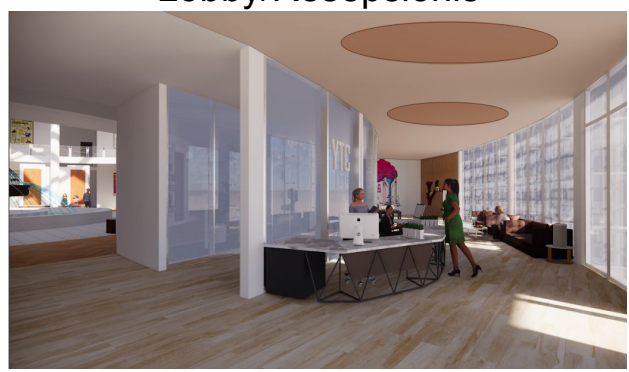

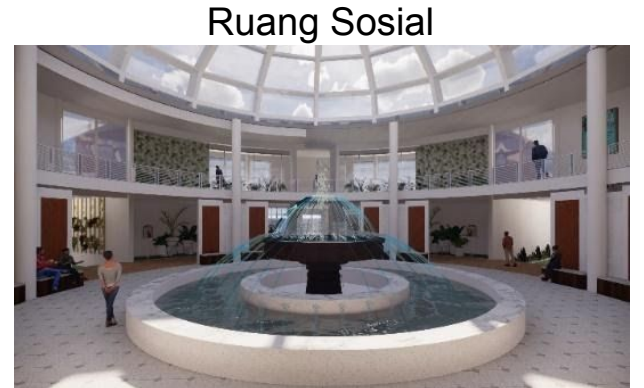

Ruang Serbaguna

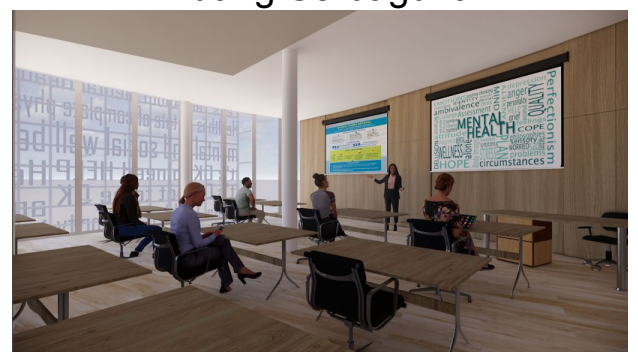

Ruang Konseling Psikiater

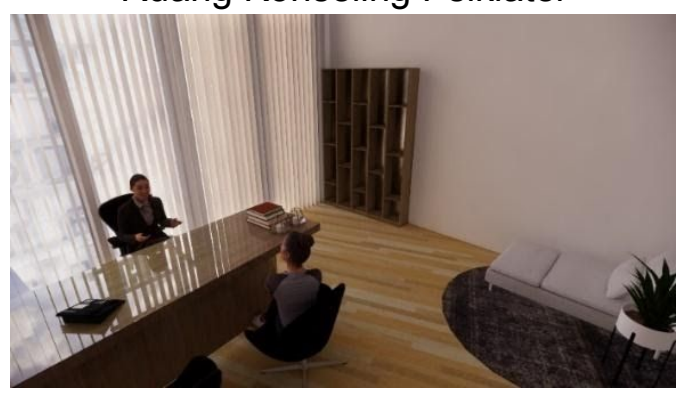

Ruang Konseling Psikolog

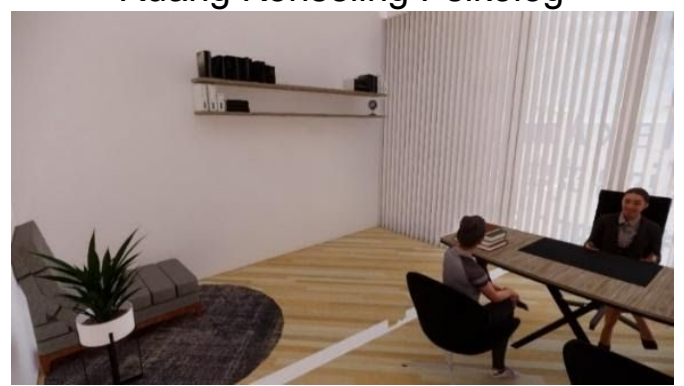

Ruang Terapi Kelompok 


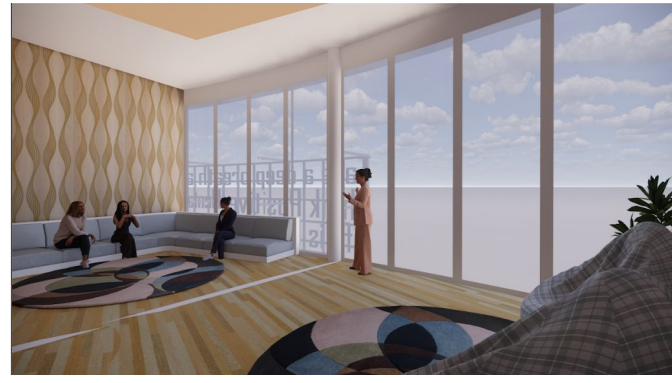

Ruang Terapi Seni

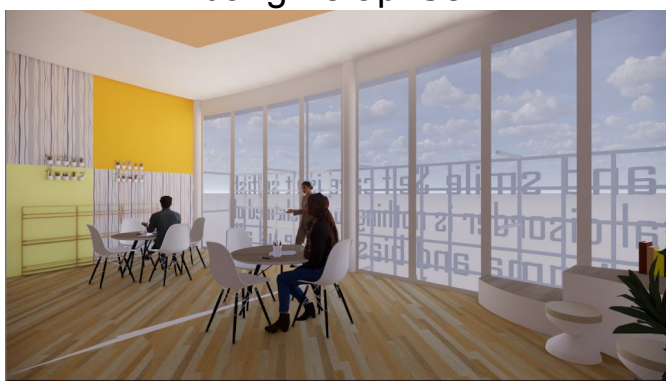

\section{Ruang Relaksasi}

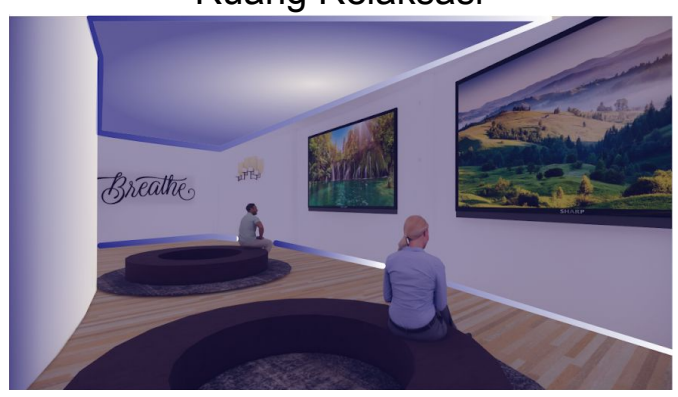

Sirkulasi

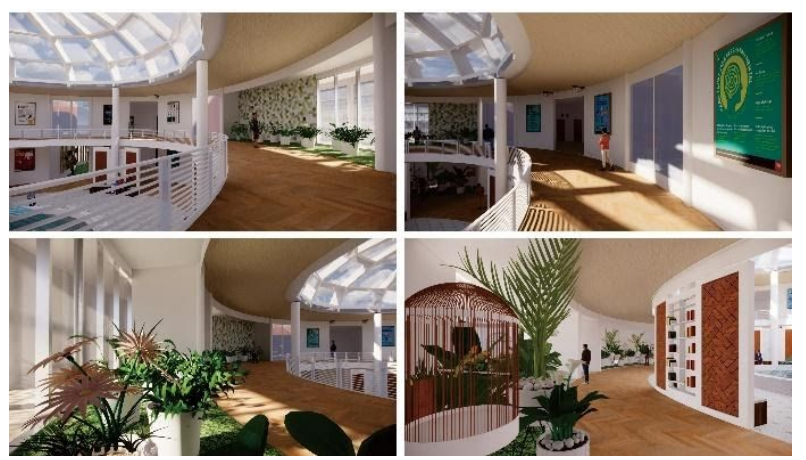

Gambar 14. Perspektif Interior

Sumber: Analisis Pribadi (2020)

1. Perspektif Eksterior
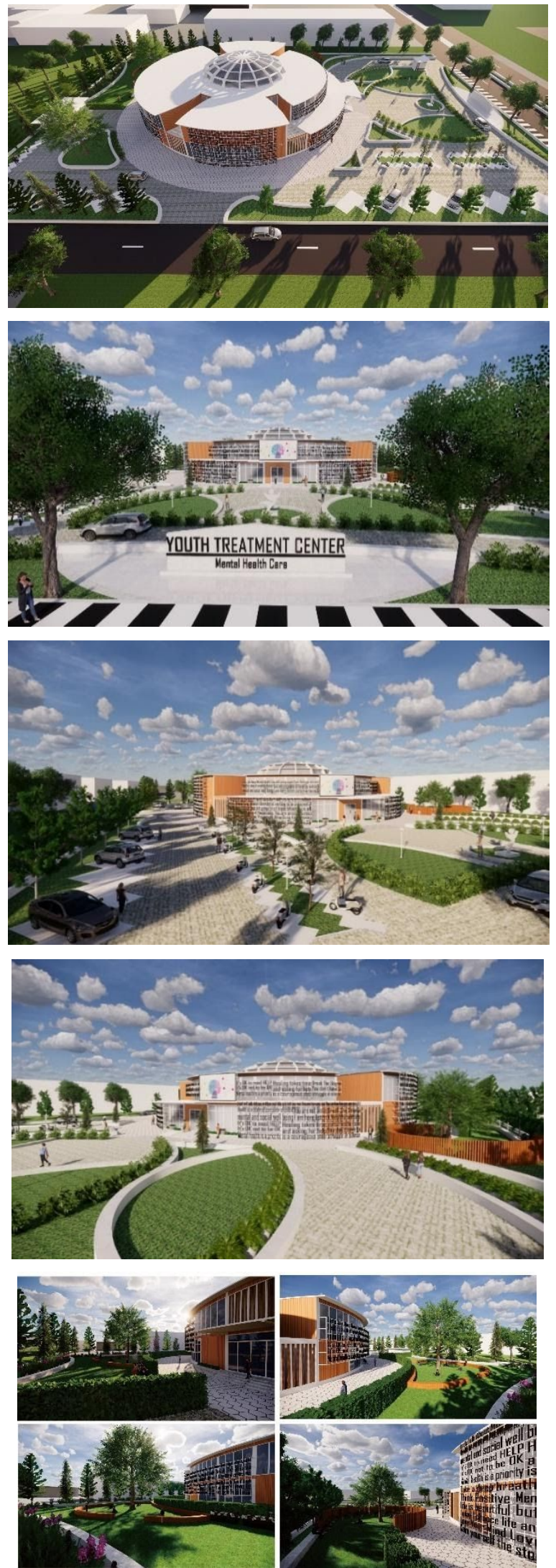
Gambar 15. Perspektif Eksterior

Sumber: Analisis Pribadi (2020)

\section{KESIMPULAN}

Youth Treatment Center Banjarbaru merupakan fasilitas perawatan kesehatan mental ringan untuk menangani gangguan depresi pada remaja serta wadah untuk memberikan edukasi dan sosialisasi pada masyarakat mengenai pentingnya isu kesehatan mental. Arsitektur, persepsi, psikologi dan citra merupakan hal-hal yang saling berkaitan satu sama lain. Metode yang digunakan untuk menyelesaikan permasalahan arsitektural yaitu teori psikologi gestalt dengan penerapan konsep space perception. Dalam mencapai tujuan rancangan untuk membangun persepsi dan citra positif bangunan, dilakukan berbagai upaya seperti pemilihan lokasi tapak yang strategis yang berada di pusat kota, menonjolkan tampilan visual bangunan dengan letter façade yang dipenuhi kata-kata positif dan bersifat persuasif, suasana perawatan yang merelaksasi dan tidak memiliki kesan menakutkan, desain yang menyesuaikan dengan karakter remaja serta adanya program edukasi dan sosialisasi sebagai bentuk kampanye mengenai pentingnya isu kesehatan mental. Sehingga seiring berjalannya waktu, diharapkan stigma negatif yang ada dapat berubah, dapat membentuk mental set yang positif, kesadaran masyarakat meningkat, serta mendukung terjadinya ikatan sosial yang kuat dan nyaman antara masyarakat dengan penderita depresi hingga pada akhirnya akan menciptakan kesejahteraan psikologis.

\section{DAFTAR PUSTAKA}

\section{Referensi Buku dan Jurnal}

American Psychiatric Association. (2013). Diagnostic And Statistical Manual Of Mental Disorders. England: British Library Cataloguing in Publication Data.
Amalina, T. N. (2013). Pembentukan Tempat yang Ekspresif Terkait dengan Persepsi Visual dan Kinestetik. Departemen Arsitektur, Fakultas Teknik, Universitas Indonesia.

Gestalt Dalam Arsitektur) . Jurnal Arsitektur DASENG UNSRAT Manado.

POP, D. (2013). Space Perception and Its Implication in Architectural Design. Acta Technica Napocensis: Civil Engineering \& Architecture.

Diananda, A. (2018). PSIKOLOGI REMAJA DAN PERMASALAHANNYA. Sekolah Tinggi IImu Tarbiyah (STIT) Islamic Village Tangerang.

Dianovinina, K. (2018). Depresi pada Remaja: Gejala dan Permasalahannya. Jurnal Psikogenesis, Fakultas Psikologi, Universitas Surabaya.

Dirgayunita, A. (2016). Depresi: Ciri, Penyebab dan Penangannya. Journal An-nafs: Kajian dan Penelitian Psikologi.

Fontine, T. (2008). Brand, Citra dan Arsitektur. Fakultas Teknik Universitas Indonesia.

\section{Website}

Miftah. (n.d.). Teori Gestalt. Retrieved from https://miphz.wordpress.com/2011/06 /06/teori-gestalt 